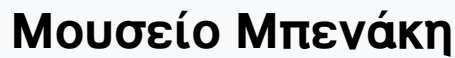

A Singular Antiquity: Archaeology and Hellenic Identity in Twentieth-Century Greece

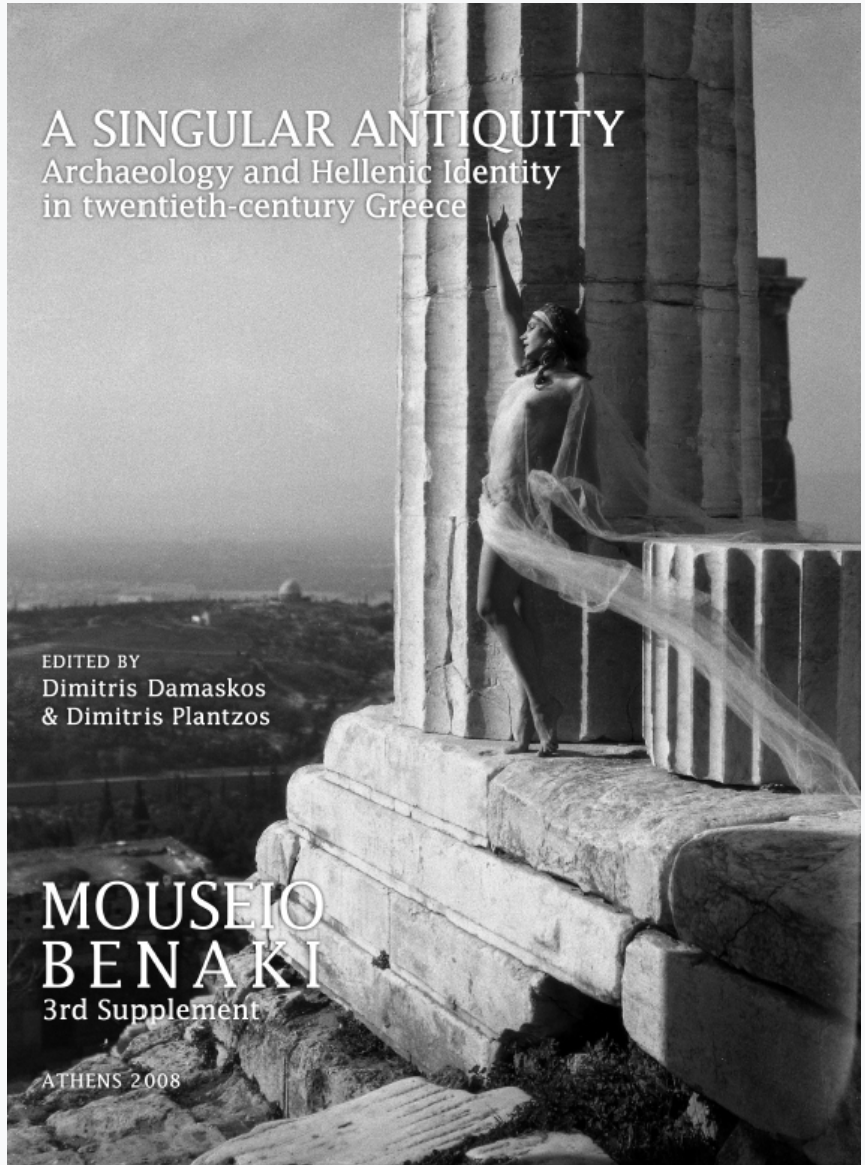

An American in Paris, a Parsi in Athens

Artemis Leontis

doi: $10.12681 /$ benaki.18063

Copyright (C) 2018, Artemis Leontis

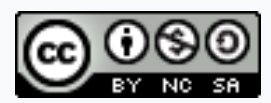

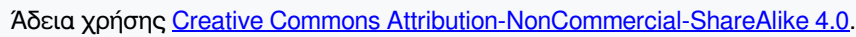

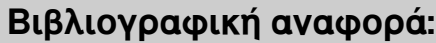

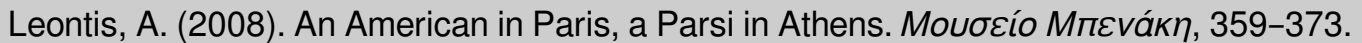

https://doi.org/10.12681/benaki.18063 


\section{An American in Paris, a Parsi in Athens}

The Delphic Festivals of 1927 and 1930 are among the most comprehensive efforts in Greece to bring the Greek past to life for a modern international audience. ${ }^{1}$ The revivals of Greek drama, arts and crafts, and athletic competitions at Delphi exemplify the idea that Greeks have a common cultural origin reaching back to antiquity and echoing in the present, and that they are uniquely positioned to reanimate it. Photographed in 1927 among the ruins of Delphi (fig. 1), ${ }^{2}$ Eva Palmer Sikelianos (18741952) producer of the Festivals, epitomizes that idea. Daughter of the eminent New York lawyer Courtlandt Palmer and an heir to the Palmer family's immense real estate fortune, ${ }^{3}$ she has just spent her inheritance on the Festival. In the photograph she appears as people remember her: classically trained, immersed in Greece, committed to reanimating its words, movements, song, and dress. She has styled her hair, layered her dress, and angled her body and head - face in profile, chest en face, as she insisted was the Greek way - in imitation of poses she observed on archaic and classical vase paintings and bas reliefs. She is wearing a tunic she designed and wove, as was her custom from the time she arrived in Greece in 1906 until her death in 1952. Her face turns away from the modern moment. She seems to stand outside time and space. Despite her American roots and lifetime engagement with modernist movements in the arts, Eva Palmer is reduced to the sign of 'Greek': she is the wife of the Greek poet Angelos Sikelianos, producer of Greek festivals, and worshipper of all things Greek, who looked back to ancient Greece for inspiration.

My purpose in this paper is to broaden the context for understanding Eva Palmer's work so as to bring into view the complexity, richness, and ambivalence of her activities. A clue to a more complex order of things can be found in another photograph, taken just two years earlier, showing Eva and Angelos Sikelianos at Epidaurus with an English tourist and two very different figures (fig. 2). ${ }^{4}$ They are Khorshed Naoroji (1894-1966) and her brother. Khorshed is wearing a simple white tunic while her brother is dressed in a European suit. From their colouring and features one recognizes that they come from the Indian subcontinent. Khorshed's traditional dress places her within time and space. It is in harmony with the image she projects as a woman at home in her Indianness. A little information about her sets her image in motion. A Parsi woman from Bombay, she is the granddaughter of Dadabhai Naoroji, a founder of the Indian National Congress, the first Indian elected to the British Parliament, and an inspiration to Gandhi. Soon Khorshed will follow Gandhi and take the khadi vow, a promise to wear homespun cloth as a step in the direction of freeing India from foreign dependence. ${ }^{5}$ Paradoxically, Khorshed Naoroji appears contemporary in her traditional clothes, her vision forward-looking, her dynamic self thrown into the promise of future independence.

Although Eva Palmer Sikelianos and Khorshed Naoroji seem worlds apart, their lives, as the second picture suggests, were briefly but intensely intertwined in a shared artistic journey. The journey began when Eva met Khorshed in 1924 in Paris, where Khorshed was studying classical music, and invited her to visit Greece. Khorshed stayed with Eva for six months. She began learning Byzantine musical notation in Athens so she could use it to record traditional Hindu songs. Returning to Paris, she spread the 


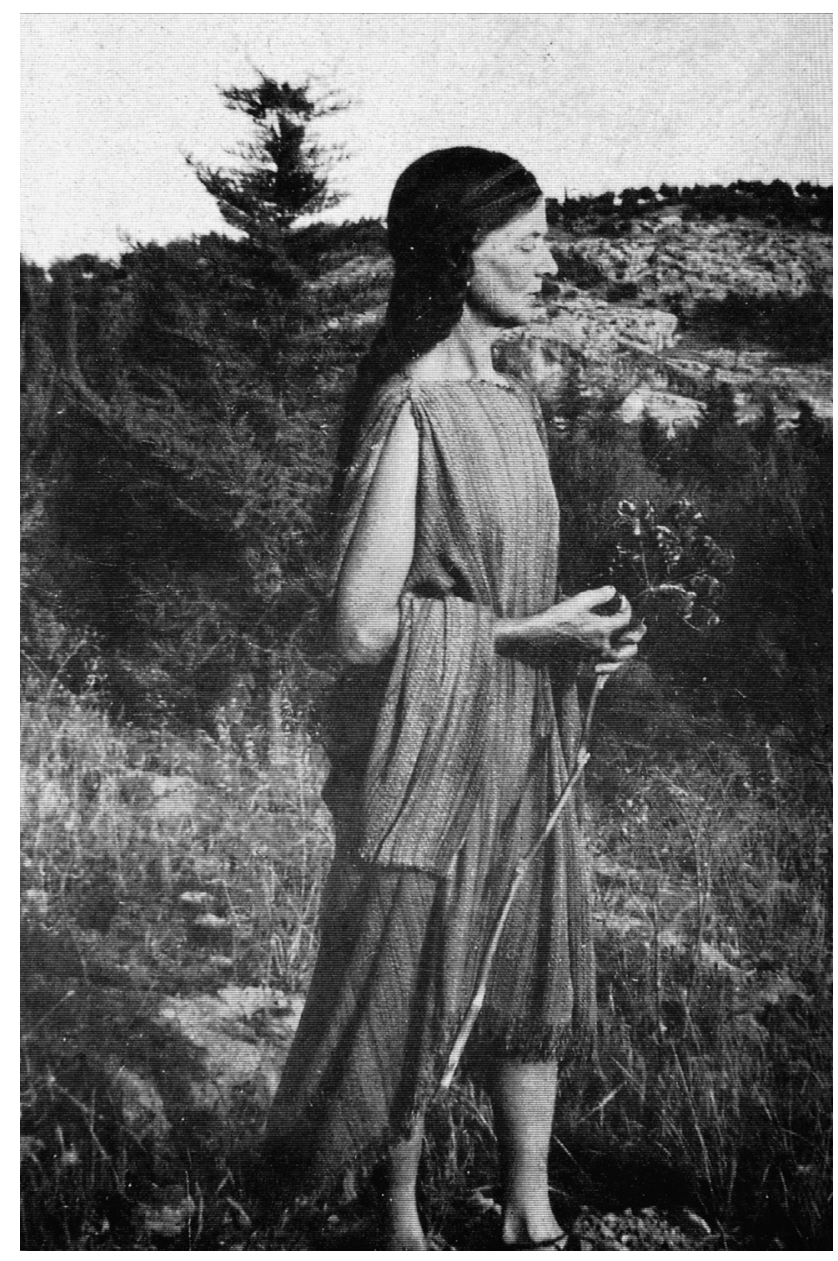

Fig. 1. Eva Palmer Sikelianos photographed in 1927 among the ruins of Delphi.

word to her Indian colleagues about the powerful tool she had found in Greece. She intended to continue as a student of Byzantine music and eventually a teacher in an international school of non-Western music that Palmer Sikelianos was working to found. But Greece also inspired in Khorshed a vision of a unified India. So instead of continuing on the musical course she and Eva had mapped out, Khorshed returned to Bombay, took up the cause of Indian independence, entered Gandhi's non-violent struggle, endured years in prison, and worked as Gandhi's secretary. At about the same time, Eva abandoned her plans for a music school and set about producing the Delphic Festivals.

In what follows I piece together the stray remains of Khorshed Naoroji's and Eva Palmer Sikelianos' collaboration. My sources are a few unpublished letters from the
Eva Sikelianou Papers in the Benaki Museum Historical Archives, passages from Eva's autobiography, Upward Panic, and from her published correspondence with $\mathrm{Na}-$ talie Clifford Barney, and sources from Gandhi's leadership in the independence movement. My intention is to bring the profiles of the two women face to face: to find in the Parsi Naoroji's journey from westernization to postcoloniality her Greek story and, in relation to that story, to recover traces of the international scene where Palmer Sikelianos was working out her ideas of how and why to be Greek. By reconstructing this story, I will explore the way in which the Greek past becomes a springboard for an unusual kind of archaeology. Rather than study the scholars and adventurists who excavated remains of Greece's past as a way of filling in missing pieces of a lost historical continuity, I focus my attention on non-Greek, cosmopolitan, female artists from opposite ends of the earth with a counter-Western, counter-philological vision, and explore how they found in the fragments of Greece's past ways of imagining the collectivity they felt was missing in the face of an increasingly dehumanized modern world. ${ }^{6}$

\section{Out of Paris}

In the spring of 1924, Eva and Angelos Sikelianos set out from their home in Sykia near Corinth to visit the factory of Steinmeyer in Oetingen, near Munich. They were expecting to preview the completed 'Panarmonio,' an organ with 42 notes to an octave, four octaves, and four registers - 1672 intervals in all. ${ }^{7}$ Eva had commissioned the organ, and Kostantinos Psachos, her Professor of Byzantine Music in Athens, had designed it with the assistance of Dr Vrachamis, a mathematician interested in the technical problems of creating microtonal sounds on a keyboard. ${ }^{8}$ The instrument was invented for the purpose of making and recording music based on non-tempered scales. Once in Germany, however, the couple learned that due to production delays the organ was not ready for trial. Angelos returned to Greece while Eva went to Paris to spend the intervening time.

Eva Palmer was no stranger to Paris. It had been her home from 1901 to 1906, when she was seeking opportunities to act but also pursuing a relationship with Natalie Clifford Barney, who, with Eva had discovered lesbian love in Bar Harbor, Maine. Those Paris years represented 


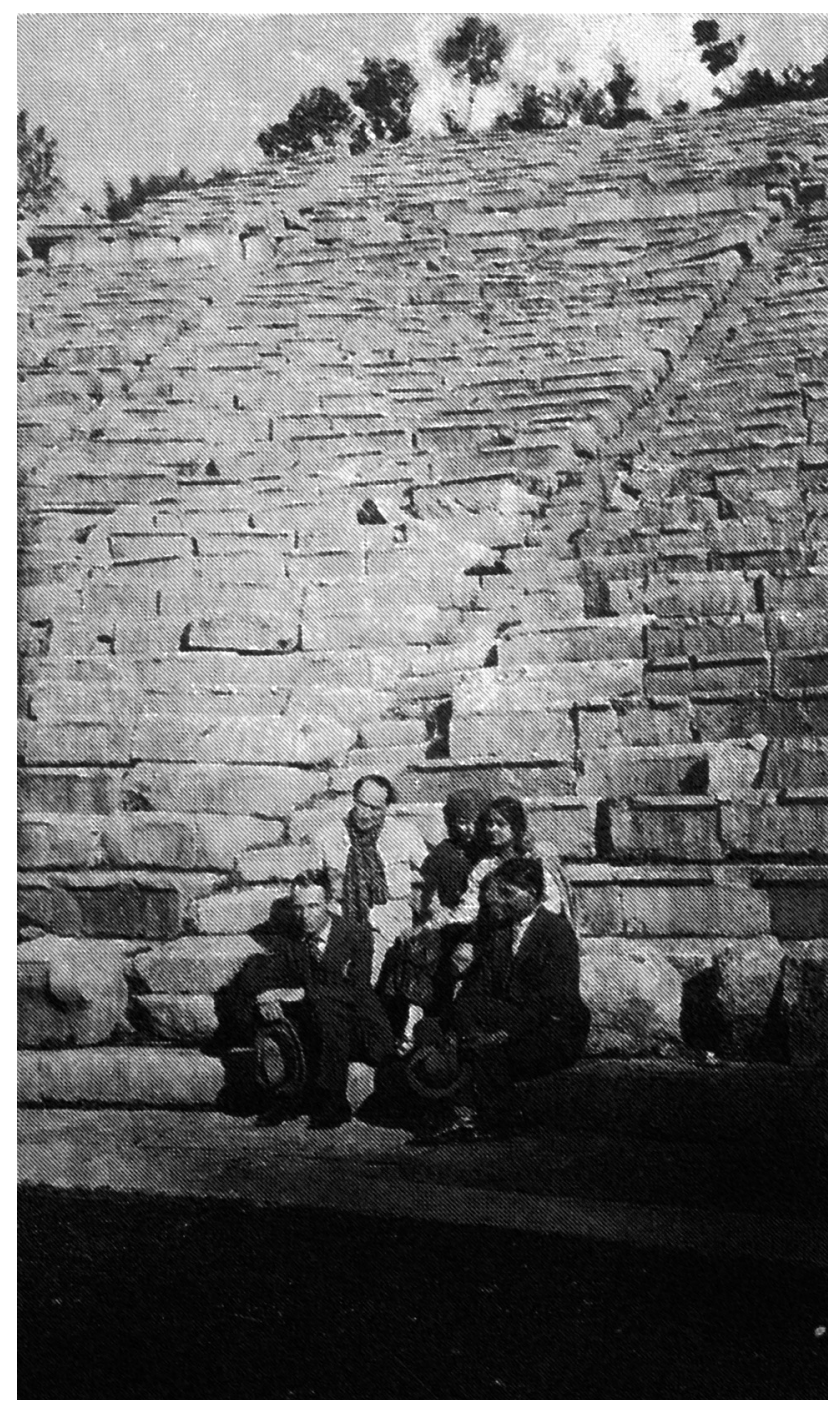

Fig. 2. Eva and Angelos Sikelianos at Epidaurus with an English tourist, Khorshed Naoroji and her brother.

an era of endless social contacts and artistic experimentation in the vast circle that Barney had created around herself. But Paris was also the place where Palmer experienced frustrated desire. Barney's endless flirtations and infidelities, on the one hand, and Palmer's own restless search for 'another theatre-consciousness', ' on the other, had exhausted her. In love and art, Eva faced a dead end.

In August 1906, Paris gave Palmer an avenue of flight from what she called the 'asphyxiating prison cell' of her passion for Barney. ${ }^{10}$ For it was in Paris that Eva met Penelope, sister of Angelos Sikelianos, wife of Raymond Duncan, and sister-in-law of the famous Isadora Duncan.
Penelope introduced Eva to the four things that would occupy her for the rest of her life: Greek music, weaving, Angelos Sikelianos, and Greece. In Penelope's singing of Greek songs and religious chants, Eva heard for the first time a style of musical performance counter to anything her Western training had prepared her for. Eva would spend the next 20 years studying that music and many more years composing in that tradition. At Penelope's side, Eva also set about learning to weave. Gradually she abandoned conventional Western clothing to put on 'a classic costume' consisting of sandals and 'a flowing gown of light material draped artistically, a three-quarter cape of the same material, and a Grecian hat'. An article in The New York Times entitled 'Looked Like a Greek Goddess' recorded Eva's explanation of this strange fashion: 'I am not a member of any so-called religious sect. [...] I dress in this fashion to be comfortable. Two years ago, owing to the distress occasioned by my wearing conventional clothing, I abandoned it. [...] I feel much happier, healthier, and more comfortable in this dress'. ${ }^{11}$ Following Penelope to Greece, Eva met Angelos Sikelianos, who became for her the 'single thread' to which she clung to escape her passion for Barney. As she wrote to Barney on New Year's Day 1908, at a time when she was trying desperately to return Angelos' love and forget about Barney: 'My love, my love, I am happy, and my happiness hangs on a single thread'. ${ }^{12}$

Greece offered new sources of stimulation, giving Eva grounds for thinking about art and life beyond the classical artefacts she had studied so many times in the Paris museums. Here she found the sweep of Greek tradition, from archaic to Byzantine to a way of life she was experiencing in Greek villages. The following excerpt from a long letter to her sister, May Suydam Palmer, written sometime during the first decade of Eva's stay in Greece, is telling. Inspired by a visit to a monastery at Damasta, a village on the northeast side of Mt. Parnassus, the letter provides a rare window on Eva's thinking as it was developing before the Delphic Festivals absorbed her on the opposite side of the Mountain. It shows her in the process of grafting herself and her artistic aspirations onto a new idea of Greekness.

'I think if I were a painter I would concentrate all my thought and energy in fresco painting. -If it be a lost art (and certainly Puvis de Chavannes, for all his beautiful work, didn't quite find the spirit of it) it would be fun to search and try and gradually invent by oneself. As a begin- 
ning it would be well to see all the Byzantine churches still in existence and stop hanging on Italian art and then by inward intuition to blend the two Greek spirits, the one before and the other after Christ, and create a third which will be old and new, Greek and universal. For such a journey one would have to go both in and out of the beaten paths and travel through Greece, Macedonia, Turkey, and Palestine. And the result in art would be both in and out of the beaten paths, having both feet firmly planted in tradition which is and always will be Greek and its head in the new world of thought and feeling which is so vital in our generation. I feel perfectly sure that the future of all arts is here in a nutshell. All have a new life in them, much greater than the old, but any art which draws away from the Greek tradition will not reach its goal. And by Greek tradition I don't mean a slavish copying of columns and statues and what not which can never give any better result than the Romans and the French have reached -but a knowledge of the nobleness of the Greek spirit which one finds and understands better by living in the mountain village than by visiting an ancient temple. In music I feel perfectly sure that its future power lies in the musical genius who will have the patience and the burning interest to learn thoroughly the Greek modes and be able to write in them, and to harmonize in the manner which Byzantine tradition permits harmony and that not because of any personal preference, but simply because the Greek musical laws are in harmony with the physical laws of acoustics just as the ancient laws of gymnastics and dancing are in harmony with the physical laws of health. In digging deep into Greek art and tradition one always finds as Quatremère de Quincy says in his beautiful work on the Olympian Zeus that the art is always based on necessity and one feels perfectly at ease whatever nation one may belong to in building one's foundations on Parnassus, -and in fact I think that if one had the courage to work out for oneself the bare necessities of life with a spirit of economy and generosity combined that the result would be Greek in whatever country one did it and without any previous knowledge of Greek art. Only by studying it one finds many problems already solved and saves time. ${ }^{{ }^{13}}$

Represented here as the spirit of the art she was discovering on Mt. Parnassus but also a potential source for all visual and acoustic arts, the 'Greek' is operating on two levels in Palmer Sikelianos' imagination. It is the particular and the universal, the art of a Parnassian monastery and a universal artistic foundation where one 'feels perfectly at ease whatever nation one may belong to'. The letter shows Eva's imagining of 'the Greek' as both a physical, geographical, historical location and a universal artistic home where anyone may belong.

That was Eva in the early years of her marriage. In Paris now in 1924, Eva enjoyed visiting with Natalie Clifford Barney after a hiatus. ${ }^{14}$ More important, she made a new friend: Khorshed Naoroji, granddaughter of the 'Grand Old Man of India'. Dadabhai Naoroji's influence on the Indian national movement cannot be overstated. In 1885 he put forth to British Parliament the 'Drain Theory,' illustrating how colonial rule was draining India of its wealth and resources, and advocated self-government. ${ }^{15}$ In 1892 he was the first British Indian to be elected a member of the British Parliament. Gandhi asked for direction and guidance from him 'as from a father to his child'. ${ }^{16}$ Yet it should be noted that Naoroji, a Parsi Zoroastrian intellectual from Bombay, who called himself a Hindu, a Muslim, a Parsi, but an Indian first, had made his money as a cotton trader and partner in Cama \& Co. ${ }^{17}$ and later as head of Naoroji \& Co.

Khorshed's interests in Paris were not in cotton, though in other respects she was Dadabhai Naoroji's grandchild. A Parsi Zoroastrian Hindu musician wearing Western clothes and studying classical music in Paris, she harboured the desire to preserve Hindu music from the very 'drain' of Western intrusions her grandfather had protested. But the contradictory elements of her life were causing her grief. According to Palmer Sikelianos' account in Upward Panic, Khorshed's classical studies were obstructing her real purpose. She had an 'India mission' (Eva's words) she could not put into effect.

'She told me that her reason for this had been that Hindu music was being quickly destroyed by European influences; that there is no Hindu notation, and therefore it is extremely difficult to do anything to counteract the inroad of phonographs, radio and jazz. She had come to Paris to learn the piano and composition, in the hope of alleviating this national need by writing the Hindu songs. But she was fearfully discouraged. She had been there years. She could play Beethoven quite well, and Chopin really charmingly; she had learned a good deal about composition. "But", she said sadly, "I must be very stupid. For still I 
cannot play the simplest Hindu melody on the piano, nor can I write any sound of my own country"'. ${ }^{18}$

Like Eva 18 years before, Khorshed was facing an artistic impasse, though she was seeking a solution to a concrete problem of national significance rather than an artistic vision of universal force. Khorshed simply wanted to find a way to recover, perform, and preserve Hindu songs threatened by colonial rule. And so Eva Palmer Sikelianos appeared before Khorshed Naoroji with a proposal, as Penelope Sikelianos had proposed to her in 1906. She may well have used Penelope's words: 'Let us go then to my country. ${ }^{19}$

The two women's journey of 1924 led them first to Germany to test the 'Panarmonio' under construction there and the principles of Eva's music school. The question was whether the system of Byzantine notation and the new instrument designed to produce the half-tones, quartertones, and microtones in Byzantine music could work for non-Western traditions other than the Byzantine. Khorshed sang Hindu songs for Professor Psachos, and he in turn notated her melodies in Byzantine hand. Eva then read his notes and was able to reproduce the songs accurately without having heard Khorshed sing them. 'You are singing my songs', Khorshed celebrated. When the organ was finally ready, Khorshed and Eva played it together. Eva wrote of their performance in a letter to Natalie Clifford Barney dated 4 July 1924:

'The small organ, which had caused me so much frustration, worked wonderfully, but the most important thing was that because of this circumstantial frustration, my Indian friend, Miss Naoroji, and I, thinking that the whole thing had failed, threw ourselves passionately into the idea of playing - and although we had little time, we gave a rather worthwhile performance. I played a few wonderful Greek liturgical pieces (slowly, since I was afraid to play fast), which showed the clarity and purity of the intervals and sound of the organ very well, and my friend, who is a very good pianist, threw herself into the labyrinth of the new keyboard with complete ease, and played Indian religious and popular songs as if she had been doing it all her life. All present were enthusiastic and asked us to repeat the performance for the villagers, who seemed equally taken.[...] Thus we made a very good impression despite the hurried organization. [...] I wish you had heard our first concert. I think it would have justified all the things I said'. ${ }^{20}$

Khorshed was convinced now of the purpose and method Eva was devising. Sometime in the early twenties, Eva Sikelianos had decided to found a 'school of modal music, ' to save the ancient oral tradition of music all over the world, but especially in Greece, because there we have a notation which can write [...] not only Greek music, but the music of any nation [...], as, for instance [...] Hindu songs, Chinese, American Indian, and so forth' ${ }^{21}$ The school would teach this notation and so become a place for preserving religious and secular songs of Greece and developing new music in Greece on a Greek basis, but also a school where 'nations which possess a musical tradition older than Bach, could, through Byzantine notation, find a way of preserving their own traditions which, alas, are now being quickly destroyed'. ${ }^{22}$ Thus in July of 1924, Khorshed followed Eva out of Paris to Greece to become the first and only student of Eva Sikelianos' music school.

\section{The archaeology of dress}

Palmer Sikelianos' autobiography offers this extraneous detail about the effect on Khorshed of her Greek journey. 'Khorshed was happy, because with me she felt free to wear her Indian clothes, which she had given up when she came to Europe'. ${ }^{23}$ As the two women travelled from France to Germany to Italy by train, then to the port of Patras by boat, then by train along the southern shore of the Corinthian Gulf, somewhere between Paris and Athens Khorshed shed her Western clothes. Eva recalled a change in demeanour together with dress, and attributed it to the fact that Khorshed found freedom in her own unconventional appearance. To readers today Khorshed's change of clothes feels uncomplicated and right, as simple as a woman's decision to throw off the accoutrements of colonization. On her was the added burden of the wealthy heiress who was parting with products that had made her grandfather wealthy. For Dadabhai Naoroji's wealth in the trade of cotton came from carrying cotton from India to England, where it was tossed onto British looms, then sewn into clothes that could be imported back to India through the influence of artists and intellectuals. Khorshed's shedding of Western dress represented an artist's recovery of her native skin. It marks her first step toward decolonization. 
How different to read of Eva Palmer's change of clothes eighteen years before! Differences lie in the many more steps Eva Palmer took, the many more old layers she took off and the many new layers she put on, all of them bound up with her elite, classically-educated, Parisian-styled, Greek-married, archaeologically-oriented, evolving American self. In France Eva first traded her American clothes for 'closets and drawers' of French ones. All the while:

'I had made an ever-renewed effort to imitate the Greek clothes we see on statues, bas reliefs, and vases. When in New York I would buy many yards of very expensive crêpe at Vantine's fine old down-town shop, stuff that really came from China, but not at all like what is now called crêpe de Chine. It was heavy and supple and therefore very good for draping in Greek folds. When in London, I would be tempted in Liberty's shop by the soft camel's hair materials and slinky silks. None of these stuffs were what I wanted, but they were the best I could find for the purpose, and out of these I made a number of dresses which at least were cut in straight lines. [...] Penelope and Raymond had made similar attempts to solve this same problem. They had found a way of pleating dresses by wetting them, twisting them tight while wet, undoing them after a day, and twisting them again several times over'. ${ }^{24}$

Improvisations with fabrics led to experimentation on the loom in 1905, with Raymond Duncan taking the lead. Raymond discovered that 'With quite a heavy warp, and a very thin weft, we might obtain the effect we are seeking. ${ }^{25}$ Then after 1906, real apprenticeship with experienced Greek villagers - 'gleaning here and there tricks in weaving that the peasant women know, and still more through an effort to discover the least fatiguing and at the same time the most rapid way of weaving by hand ${ }^{26}$ - produced a certain kind of cloth, an agility with design, and a way of living and being that Palmer Sikelianos would wrap herself in for the rest of her life.

Eva Palmer Sikelianos' exchange of Western clothes for Greek-inspired attire required a complex, empirical archaeology, used to recover an ancient method of production, together with a folkloric interest in the lives of Greek villagers. There were neither the original tools nor extant artefacts to imitate, only the traces of those tools and their artefacts as seen in art, and the vestiges of ancient practices in everyday life. She and the Duncans observed visual sources; but they found their method by trying to reproduce in their cloth the visual effects. In the end she would receive confirmation from archaeologists who, as Joan Jeffreys, wife of Agora excavator Eugene Vanderpool, reported to Eva:

'while excavating a Geometric tomb [...] came upon evidence bearing out the theory of Eva Sikelianos'. It seems they found an iron object which had lain against the shroud of the body buried in the tomb; and which, during the process of rusting, had picked up the imprint of the cloth. It clearly showed the pattern of the weave: a heavy warp, and an almost imperceptible weft. $\mathrm{Mr}$ Morgan said that it not only proved [Palmer Sikelianos'] theory, [...] but it showed that ten centuries earlier in Geometric times, this method was used for the same reason: to produce the richness of folds seen through Greek and pre-Greek vase painting. ${ }^{27}$

Rather than identifying herself as an archaeologist and folklorist, Palmer Sikelianos described her investigation of these archaeological questions as a matter of social exigency. Her archaeology's end was not to develop a sound, scientifically reproducible theory or to win professional approval but to promote a lifestyle of making and using handcrafted everyday materials, which she felt to be a matter not of taste but of advancing a well-functioning society comprised of creative individuals. This was this alternative model of production she believed Greeks could provide the modern world to stave off its dehumanizing effects:

'There is something alive about the loom, something eminently sociable on the one had, because of the different stages in setting up a warp where several usually work together, and something restful and rhythmical in loneliness when the swift shuttle seems to clarify one's thoughts, much better than merely lying down or sitting idle in a chair.

[...] Let the Greeks then use their special talents, and thus provide for themselves, and for those in all countries who still care for such things, objects useful to life and unique in beauty, with the inimitable quality that only human hands can produce. In this way they will secure an enviable living for themselves, and at the same time eliminate one nation from mechanical competition'. ${ }^{28}$

Next to Khorshed's straight exchange of something foreign 
for something native, the contrast of the long process of Eva's archaeology, experimentation, and theorization is quite striking. Eva's quest for something natural to wear developed into an archaeological method and a social theory of dress. Guided by these principles, she finally clothed herself as no one around her cared to. In Greece, a country whose population was anxious to approximate the most stylish of Western dress in an effort to find its own modernity, she stood apart in her Greek-style, hand-woven tunics. Try as she might (and she did try), ${ }^{29}$ she was unable to convince Greeks to exchange their Western-inspired clothes for her version of native dress. Only the Indian Khorshed Naoroji followed suit. Perhaps Khorshed's path to nativism was more mediated than her image would suggest.

\section{Mother Greece/India}

So far I have talked about the non-Western music that moved Khorshed to travel to Greece and the change into native Indian dress that came about while she was travelling. Now I would like to explore what the Greek landscape signified for her.

The stretch of railroad lines along the south of the Gulf of Corinth inspired in Khorshed another powerful set of feelings. As she would later write to Eva, Greece 'caressed' her like a mother. But we know from Eva that the future of India was also on her mind. According to Upward Panic, Khorshed 'was absorbed in what she was seeing from the car window' ${ }^{30}$ She 'made the statement that she felt as if she were seeing India', but India 'all joined together; as if she were seeing North, South, East, and West all in one, "A sort of essence," she said, "of India"'. ${ }^{11}$ Back in Bombay, Nurgis D. Captain anticipated that 'our baby sister' Khorshed was talking to Eva about India. So he wrote to 'Madame Sikelianos' on 8 August 1924 of the dark realities of India and the benefits he hoped Khorshed might receive in Greece.

'I wonder if you have ever been to the East? I hope Khorshed does not only point the glories and colo[u]rs of the gorgeous east of song and story, but gives you also some idea of the tragic fall of her people, the cause of the shackles they wear now. However in the middle of gloom we have the glory of possessing a Gandhi and that gives one hope and courage to struggle on. I hope Khorshed will benefit in health from the change to your [...] beautiful country under your good care. [...] Perhaps in other births and other years neither country nor race divided us. ${ }^{32}$

Both sources touch on the subject of India as a haunted, shackled, divided place with a glimmer of hope, while they present Greece as a place with the power to join things. Just the smallest sense of historical context reminds one, of course, that 'beautiful' Greece, the essence of what India might become, in Khorshed's imagination, had only recently taken its present geographical shape. In the process of trying to achieve an even greater geography, Greece had endured a national schism and then the Disaster of 1922 just two years prior to Khorshed's imagining in the refugeefilled Greek state a unified, complete, and whole India.

That a foreign visitor to Greece was superimposing on Greece a vision of her own desired national collectivity is not in itself surprising. For the past two centuries Greece has existed as a portable idea, a kind of topos standing for whatever is great in Great Britain, Germany, France, or America, or occasionally whatever is wrong with the world. Moreover, as readers of travellers' tales to Greece will recognize, people visiting Greece regularly find in the landscape a Greece a prototype of their homeland or whatever else is on their minds. Thus it is not uncommon to find in travellers' accounts a vision of another homeland. In this context Khorshed Naoroji's vision of India superimposed on the Greek landscape is neither startling nor new. What is unprecedented, to my knowledge at least, is the Greek-inspired vision of a united India - not just because it is India, and Indian travellers to Greece were rare, but also because it is united, and a united India did not exist. One sees for the only time here, I think, a traveller to Greece finding in Greece the determination to work for the cause of freeing all of India from colonial rule.

As one traces the path that led Khorshed from her mission of recovering Indian music to the cause of Indian independence, one finds at each turn a Greek moment. Eva's organ and Byzantine notation gave Khorshed a method for realizing an amorphous dream she had been nurturing of recovering Hindu songs. Her journey to Greece moved her to change her style of dress. Her first view of Greece broadened her vision of herself in the world to include a dream of India joined together. From her base at the Sikelianos home on the Gulf of Corinth at Sykia, this landscape of an 'essence of India' was in everyday view. From Sykia she travelled back and forth to Athens to study with 
Professor Psachos. She also moved comfortably back and forth between Eastern and Western forms of music. To her hosts Khorshed became 'Boul-Boul', from the Persian word for nightingale. She entertained them with a medley of Indian dances, songs, 'jingling bracelets of little bells', and 'fascinating instruments' from which 'her tiny hands and delicate wrists would bring out extraordinary resonance'. ${ }^{33}$ Or she sang Ravel's songs, including, most likely, his Greek songs, accompanied by another frequent guest at the Sikelianos home, the Greek pianist and conductor Dimitris Mitropoulos, who would go on to become 'director of the Symphony Orchestra in Athens. Since then, to our joy, he has gone from one triumph to another' ${ }^{34}$

Relations between her and the members of the Sikelianos family became exceedingly close. Khorshed called Eva 'Mummy' or 'Mums'. She was 'my six month mummy, my mummy for always'. ${ }^{35}$ As she explained in a letter to Eva, 'You are Mummy. I am not blind to your faults but I bow my head before your simpl[e] devotion. Never have I seen such an example in the West and I am certain there are very few like that in the East'. ${ }^{36}$ She signed her letters 'Bul' or 'your Baby Bul'. Sometimes there was desperation in her desire to please Eva. On those occasions she might inexplicably shift genders in the pronouns referring to 'mummy': 'Mummy, darling, he's not going to drop his Baby if Baby can't manage to be proud? ${ }^{37}$ She might even comment on the gender switch:

\footnotetext{
'Also I hope I shall take the khadivows that means the social nibs of Athènes (sic) will have no use for a poorly dressed female. Mummy will not see his baby any more in silks and gold but he'll love him all the more. I've got rather mixed up in the gender'. ${ }^{38}$
}

The very little one can gather about Khorshed during this period and scant sources of deeply personal information that Eva Palmer Sikelianos did not destroy or hide tempt one to read things into Khorshed's words. What can they mean? At least this: that Eva stood in her imagination as a generous mother figure, equal to few women she knew even in the East, and at the same time as a kind of male figure testing her conscience.

Khorshed also expressed great affection for Eva and Angelos' son Glafkos. Indeed she tried to repay her debt to Eva by taking on the cause of Glafkos. At some point she tried to help Eva find a place for him to study in
India, and promised a surrogate mother not only in her own Indian Mummy but in herself, though she worried that her family's 'regime' would be too 'severe' for him and argued desperately that he belonged in Greece in his mother country with his mother. Her letter to Eva dated 20 December 1924 is notable for the number of times it mentions mothers, the number of people slipping into a motherly role, and the ways 'mother' represents both the mother of a family and the 'mother country', with the one potentially taking the place of the other. Khorshed senses danger for Glafkos in the slippage, and offers the opinion that Glafkos should stay near his mother Eva, but also near 'his Mother country', which, in the end, cannot be like any other: 'no two countries are alike however high may be their ideals. My opinion as a woman with motherly instincts suggests that he should stay near you and see the world through your love and your great sacrifice'. ${ }^{39}$

Here we see for the first time Khorshed's insistence on the differentiation of countries. India cannot be Greece for Glafkos. Are we to infer that Greece cannot be India for Khorshed? Yet for some time Khorshed, in a chain of associations that flooded her after leaving Greece, saw herself as a child responding to Greece and Greece as Mother Earth touching her:

'I cry like a child when I hear Greek. I follow people in the streets when I hear the language. Perhaps I've shown no natural sign of recognition or appreciation; but no country through the medium of Mother Earth has touched me as much as Greece. Humanity has failed me but I suppose that was to be. It's one of the phases of my life'. ${ }^{40}$

And: 'The blue sky of eternal Greece is in my heart. Wading through the barren country [...] with its patches of snow, my "self" sees but your country'. ${ }^{41}$ Khorshed expressed her love for Mother Greece openly in Paris, speaking of her collaboration with Eva and of her intention to return to Greece to continue her studies. She wrote to Eva of the jealous wrath of fellow Indian students, who tried to guard the 'Mother's call' for India alone:

'The Indian students of Paris are in open rebellion against me. After hearing what I was intending to do in Greece, they are furious that I should have left even at a Mother's call. One of the students said in our last meeting "You have no mother but Bahra Mata (i.e. Indian name for In- 
dia) no family but her, her service is your duty"'.42

Yet her devotion to 'Mother Greece' was strong enough that she determined to give 'a short account of my visit, your new organ, the necessity of Byzantine notation for the preservation of Indian national music, on the 28th'. ${ }^{43}$ And she managed with that talk on 28 December 1924 to inspire devotion for 'mother Greece' in those same Indian students:

'I did speak something about Greece, its music, its people, lastly its situation with regard to the part being played by the western nations in its present development. The latter part wasn't well received by some French people; in the debate it brought some nasty cuts on my motherland. However it worked up the enthusiasm of the Indian students. One (in the Association) is seriously thinking of sending some ten students chosen from amongst all the Indian students in Europe to Mother Greece. I am surprised to see that quite a number of them have a knowledge of the ancient Greek language. We had the good fortune to have about fifty of our students from the English University come on a visit to Paris. I am going over to England sometime when we have much more definite plan $\&$ lay it before our Indian Association in England. It was so beautiful starting to have my country talk about Mother Greece. I have never heard them use the sacred name of mother in connection with any country except India. If only you could have been a silent observer... There was no Greek to hear us but Mother Greece was in our hearts' ${ }^{44}$

However warmly Khorshed may have felt toward Eva, however motherly her experience of Eva's hospitality and, by extension, the reception of the whole of Greece, Khorshed came to the realization that Eva's dream of Greece could not be her own. Clearly some tensions existed in the triangle of Khorshed, Eva, and Angelos, which made Khorshed fear some kind of misunderstanding. But where Khorshed really could not follow Eva's lead, where she drew the line, was on the site of the Acropolis. We learn of this through an apology she felt the need to offer to Eva:

'My darling, there is just one thing I want to mention about your letter about my having stayed out of the Parthenon when I was at the Acropolis. Mummy, don't let there be any misunderstanding between us. I'm not saying this to support my attitude but you must make allowances for human weakness. My heart was very sore. [...] the evening before I left Sykia to come to Athens. I am sorry but the knowledge and friendship between Angelo and myself has been a great misunderstanding from the very beginning. ${ }^{45}$

Like so much else in the strange story of the meeting of an American and a Parsi Indian on Greek soil, the scene touched on here represents an under-documented moment. The letter offers a brief trace of the scene and a personal explanation. It tempts readers of a letter meant not to be read by anyone but its recipient to imagine a difficult triangle of relations motivating Khorshed not to enter the Parthenon. Perhaps she had experienced the melancholy of a divided heart: one devoted to Eva for her motherly affection and guilt-ridden for her 'friendship' with Angelos, which had surpassed the boundaries of innocence. Here one is reminded of Sigmund Freud's analytical reduction of his 'divided' response to the Acropolis. In his 'Disturbance of Memory on the Acropolis', Freud rationalized his feelings of alienation, his lack of enjoyment in a visit he had anticipated with pleasure, in terms of his guilt-ridden feelings of having 'excel[ed] one's father'. He saw in his response 'filial piety' for his uneducated father, who 'had had no secondary education', to whom 'Athens could not have meant much'. ${ }^{46}$ Khorshed explains her resistance to the Parthenon in terms of her misunderstood feelings for Angelos, Freud in terms of his suppressed fear of having surpassed his father. Khorshed's and Freud's explanations are equally incredible. Yet Khorshed's letter also offers an opening for other interpretations, without suggesting what they might hinge on: 'but if there are other opinions on the subject I'm prepared to accept them'. ${ }^{47}$ Perhaps the element worth hanging onto here is the image of the Parsi Indian Khorshed Naoroji, who was not just the granddaughter of Dadabhai Naoroji but a descendent, in one way or another, of the Persians who 2400 years before had destroyed the buildings on the Acropolis. The modern Parsi, a woman of class, education, and means, passes through the Propylaea in her traditional dress. Eva and Angelos Sikelianos are leading her to the steps of the Parthenon, full of enthusiasm for what they are about to show her, hoping that they will convince her of the necessity of Greece. Khorshed feels the complexity of her relations not just with the couple but with Greece. Her love for Eva, the devotion to the Greece Eva has shown her has taken 
root as an analogy for the suffering, beauty, grace, and potential of India she longs to embrace. Her allegiance lies elsewhere, in a parallel but incompatible universe. Khorshed disappoints her hosts by refusing to enter.

Khorshed would not have been the first visitor to Greece to feel ambivalence while facing the Parthenon, though she would have done so without the Westerner's baggage of a classical education. Here the woman from the East found her own reasons to resist the Parthenon's draw, reasons that slip out of our hands.

\section{'Yoga' garment}

Khorshed's musical ambitions took the shape of concrete plans in the months between December of 1924 and her return to Bombay in September 1925. Her return home, however, brought matters to a head. On 3 September 1925 she wrote Eva of her 'great great disappointment' in the state of India:

'[...] Motor cars have increased as well as cheap European finery. Somehow European stuffs and colores (sic) look so tawdry in the Indian sun.

India is unhappy: the poor are poorer than before. I can't see anything clear. I wish very often that I hadn't been born. I hate to live in the house I'm living and hate to see so much waste of food and go about in a car when millions are starving. ${ }^{3} 8$

If anything, Khorshed's disappointment strengthened her determination to open a school of 'purely Indian music' rather than an 'Academy of European music'. But it also located another 'way out' of an anticipated impasse with her family. For her family did not approve of her plan. Khorshed anticipated a showdown and planned her escape by an alternative path:

'I shall give my ultimatum to the family that I begin my work in Indian music with a view to a profession as soon as I can grasp it. If not I want to try yoga. I do not wish to try to begin an Academy of European music before we have a good one of purely Indian music. I won't go against my principles. I daresay I shall find my way out. ${ }^{\text {'99 }}$

Two weeks later, Khorshed responded to a letter from Eva requesting assistance with her preparations for the Delphic Festivals. Khorshed's letter serves as a reminder of the turn Eva Sikelianos was taking away from her School of Music. Indeed, on the day she arrived with Khorshed in the port of Patras, Angelos proposed that she help him move ahead with his Delphic Idea and asked her to direct an ancient Greek play. So, while Khorshed was singing her Indian songs and playing her Indian drums and performing Ravel with Mitropoulos, and while she was travelling back and forth to Athens, Eva was reading Yannis Gryparis' translation of Prometheus Bound and auditioning Greek composers. From this point on her attention would remain focused on Greek drama. In her letter of 16 September 1925, Khorshed complained of Eva's months of silence but accepted 'the colossal work before you'. She then made this promise in response to a request Eva must have made in a letter I have not found:

"About the "yoga" garment I could have it spun, woven, and dyed here. The white sample is the sort of stuff [the fabric is made of.] [The other sample] is for the colour. The shape is a simple long tunic with short sleeves and just above the ankles with two splits at the side. [...] Please send me the measurements from the middle of the shoulder to just above the ankle front-back. ${ }^{50}$

Here the collaboration between Khorshed and Eva took a tantalizing turn. The two women were about to veer apart. Khorshed was announcing her first ascetic steps away from music in the direction of yoga, khadi, and Gandhi's independence movement, political engagement that lead her to the North Frontier Province to work in educating women and teaching them to spin, ${ }^{51}$ and for which she spent years in prison. Within a few years, Gandhi would write approvingly of Khorshed's character and contributions to the movement: 'Khorshed Naoroji over 30 years in age, a woman free of hysterics, full of faith and spirituality, went to the Frontier, lived with Abdul Ghaffar Khan, came in intimate touch with people'. ${ }^{52}$ As Gandhi's secretary 19 years later, her words and actions would beguile the American magazine Time:

'Khorshed Naoroji, who heads Gandhi's foreign secretariat, is a slim Bombay Parsi with an easy sense of humo[u]r and a pleasant, informal manner. Her grandfather was Dadabhai Naoroji, first president of the Indian National 
Congress and first Indian member of the British Parliament. She was recently released from prison. First jailed (for her political views) in Bihar, she was moved under escort of eight armed policemen and one wardress to the Poona jail. On the train the sleepy police men handed her their revolvers to guard. She asked: "How can you dare do this?" Answer : "Oh, we know you're nonviolent". ${ }^{53}$

I have not discovered if the 'yoga garment', the product of Khorshed's ascetic turn and Eva's Delphic mission, ever reached Greece; but I have no reason to doubt that it did. Khorshed's dedication to Eva on every other occasion suggests she followed through. It is interesting to note, too, that in a letter dated two weeks after the 1927 games, Khorshed invited Eva to come to India to give advice on weaving:

'[...] will you turn your attention to India for a bit? I would suggest your coming from November to April if you can't stand the heat. I should think it would be interesting if you see all the weaving centers and gave us suggestions. ${ }^{54}$

The single garment Eva ordered would have served as a prototype. Perhaps Eva used it to design costumes worn by athletes or the costume she designed three years later for Danaus in her 1930 production of The Suppliant Women. More tantalizing still, perhaps this model of simplicity in design and economic independence in Gandhi's movement was the costume of Prometheus, the protagonist selected as a national and international figure of human suffering. The costumes of all these characters fit Khorshed's description. Whatever the case, the idea that a handspun garment from India somehow entered the Festivals has a special resonance. The 'yoga garment' Eva commissioned would have been spun, dyed, and woven under conditions that made the very act of spinning, dying, and weaving a centrepiece of India's revolutionary independence movement. It conjures up the image of Gandhi, bare-chested and rail thin, dressed in simple white cloth in solidarity with India's peasants, sitting at the spinning wheel and showing khadi to be a principle of revolution equal to Satyagraha, nonviolent non-cooperation. It adds to Eva Palmer's hard work of weaving all those costumes a temporal anchoring, international scope, and political direction that, without the unexpected Indian connection, one could hardly imagine.

At the same time, the spectre of an Indian-woven garment, camouflaged somehow as Greek in the Delphic
Festivals, also confirms the Greek-centredness of the Delphic Idea. For it shows how completely Eva Palmer Sikelianos' efforts to forge a new collectivity from an array of elements, several of which were not Greek, were made to fit into a mould of Greek revival that could not accommodate any significant deviation. Despite her international idea, expressed in the letter I quoted earlier, that 'one feels perfectly at ease whatever nation one may belong to, in building one's foundations on Parnassus'; $; 5$ despite her dream of making Delphi a supra-national home; despite her many invitations to world-eminent figures, sent westward to well-known artists, intellectuals, politicians, and scholars, and eastward, yes, to Gandhi and to the Bengali writer, philosopher, visual artist, and composer Rabindranath Tagore (for their apologies exist in the Eva Sikelianou Papers, Gandhi on 6 January 1927 declining because he had a political movement to attend to, Tagore on 2 March 1927 excusing himself for lack of resources and time but promising one day to come to 'your beautiful country' to meet Sikelianos and arrange 'for writing down my songs in Greek notation'); ${ }^{56}$ despite all her international reaching and cosmopolitan spending, Eva Palmer Sikelianos' effort to create an alternative musical and theatrical consciousness were received as a kind of modern Greek classicizing orthodoxy. Her work became identified with a form of aesthetic nationalism that excavated the Greek past for the purpose of confirming Greek artistic continuity.

Yet pieces from the still unexplored record of Eva Palmer's collaboration with artists from musician Khorshed Naoroji to dancer and choreographer Ted Shawn suggest that Eva Palmer Sikelianos' ideas of Greece served as catalysts for political and artistic projects of improbable scope. The Greece Khorshed Naoroji discovered through Eva Sikelianos became the springboard for a collective imagining of political resistance to the modern Western world. Resistance initially took the form of embracing non-Western music, but eventually led to rebellion against British colonialism. Khorshed's journey to Greece inspired in her an Indian dream. Through the suffering she experienced as she worked to realize this dream, Khorshed learned to embrace all of humanity in her striving for non-violence and truth. It would be inaccurate to say that Greece led Khorshed to embrace non-violence. But it would be equally wrong to imagine that without her Greek journey with Eva Palmer in the lead, Khorshed Naoroji would have 
shed her Western dress, abandoned her studies in Western music, envisioned a united India, or embraced Gandhi's ascetic approach to revolution in quite the way she did. A letter she wrote to Eva on 24 January 1936 shows how far Khorshed's collective imaginings had taken her, and how much her memory of Eva mattered to her:

'Nepean Sea Road

Bombay

January 24th 1936

My dear dear Eva,

Miss Macleod gave me your New York address. Meanwhile I had been writing to Athens with no luck.

I would like to hear from you and I would like to send you all our future publications on non-violence and have sent you today a small brochure on the Satyagraha which had to be done rather hurriedly because of the Indian Natural Congress Jubilee.

Eva let us take up the thread which was broken off some years. Prison life has given me a fuller life and I wish to embrace all humanity because life is all. Through suffering I have come to joy. Years of prison life, coupled with solitary confinement has left me weaker in body but the spirit is free and ready to strive for non-violence and truth.

Write to me Eva. There is no hope of seeing you but you are always with me.

With love from Bul.

P.S. In case you have forgotten my name.

K.A.D. Naoroji ${ }^{57}$
Eva Palmer Sikelianos and Khorshed Naoroji's collaboration brings to the foreground the cross-threads of twentieth-century uses of the Greek past. These two women are some of the female and male artists who stood at an oblique angle to the prevailing fashions of their day. Their modernist sensibilities moved them to resist dehumanizing forces in the modern world. Like contemporaries such as Pablo Picasso, Isadora Duncan, Natalie Clifford Barney, Giorgio de Chirico, Sigmund Freud, and so many others, they found in elements of the Greek past ammunition to contest western orthodoxies. They were not purists in their approach to the Greek past, but instead mixed it with other cultural elements: Byzantine with classical, Indian with Greek, politics with art. Their end was not to reconstruct Greek antiquity or solve archaeological problems but instead to breathe new life into its fragments so as to move audiences to embrace the aesthetic, political, or emotional truths that mattered to them. However tangentially Greece may have touched Khorshed Naoroji, her passage from studying classical music in Paris to embracing non-violent struggle against British colonial rule in India by way of Greece bears witness to the incredible reach of Eva Palmer's counter-archaeological, counter-philological, counter-classical vision. At the same time, the tendency of critics to fit Eva Palmer's eccentric approach to Greek tradition into a conventional mould of Greek revivalism shows how easily a radical, hybrid conception of Hellenism can lose its sharp edge.

Artemis Leontis

Department of Classical Studies

University of Michigan

aleontis@umich.edu 


\section{Notes}

1. I am grateful to the staff of the Benaki Museum Historical Archives and to Lia Papadaki for assisting me with research in the Eva Sikelianou Papers. I also thank the Program in Hellenic Studies at Princeton University for inviting me to present and discuss this paper, and the following individuals, who prodded me with useful questions and suggestions: Sayan Bhattacharyya, Dimitri Gondicas, Alexander Nehamas, Dinyar Patel Yopie Prins, Effie Rentzou and Elizabeth Wingrove.

2. Eva Sikelianou Papers, Benaki Museum Historical Archives 189/4 \#410.

3. Courtlandt Palmer's obituary of 24 July 1888 in The New York Times, entitled 'Courtlandt Palmer Dead', called him 'a typical wealthy New-Yorker with an abundance of leisure', and stated that 'by profession he was a lawyer, and he was born in this city 45 years ago, the son of Courtlandt Palmer, who left his heirs a large amount of real estate on New York Island' (The New York Times, 24 July 1888, 5).

4. Eva Sikelianou Papers, Benaki Museum Historical Archives 189/3\#354.

5. Khadi means cloth woven on Indian hand looms from handspun cotton, silk, or wool. Gandhi popularized its use during India's movement for independence from colonial rule. He elaborated on its significance in a treatise, Khadi, Why and How (Gandhi 1955). According to Parel 1969, 516, the values Gandhi associated with khadi were 'economic regeneration, mastery over machinery, empathy between the rich and poor', while the 'congruent virtues' were 'poverty, truth, fortitude', and 'relevant actions' were 'production, distribution, and wearing of khadi; ceremonial spinning; action to improve villages; burning of foreign cloth; boycott of foreign cloth; khadi franchise'; organization of spinners' association. Parel 1969, 517-20 gives a succinct description of the symbolic value Gandhi attached to khadi and the economic theories supporting its symbolism.

6. Roessel 2002 rightly identifies a pattern of foreigners' uses for Greece in the first half of the 20th c. He writes that 'foreign Hellenes constructed cultural continuity in Greece to defend their individual identity in the face of the dehumanization in the modern world' (164). Beyond self-discovery, which became a trend in travel writing about Greece especially after Henry Miller circulated The Colossus of Maroussi, one finds that a select group of travellers used Greece to re-imagine collective identity in the West. It is not especially odd that Roessel overlooks Eva Palmer Sikelianos in his discussion, since until recently people identified her so fully with her husband's Delphic Idea that they didn't think of her as a 'foreign Hellene', a traveller, or an expatriate from the United States. Her case is not unique among travellers but is extreme in its lifelong intellectual engagement and personal investment in Greece. Indeed, Palmer Sikelianos' case leads one to expand on Roessel's definition of the 20th c. traveller's encounter with Greece, since Palmer Sikelianos tried to find in Greece not just an individual identity but a counterdiscursive model of collectivity for modern living.

7. Palmer Sikelianos 1993, 98. A small version of the 'Panar- monio' (sometimes dubbed 'Eveio', in honour of its sponsor) has been conserved by the Centre for Research in Greek Folklore of the Academy of Athens and was presented at an event honouring Kostantinos Psachos on 30 November 2007.

8. Palmer Sikelianos 1993, 97.

9. Palmer Sikelianos 1993, 45.

10. Eva Palmer letter to Natalie Clifford Barney from Lefkada dated 'New Year's Day' (1908), in Papadaki 1995, 282. As I have not yet obtained access to the original correspondence between the two women, which was in French and English, and the only published version exists in Greek translation, I am forced to translate (however awkwardly) into English what was originally written in this case in English, and so only to approximate what Eva Palmer wrote.

11. New York Times Archive, September 1, 1907.

12. Eva Palmer Sikelianos letter to Natalie Clifford Barney dated 1 January 1908. Papadaki 1995, 286.

13. Letter from Eva Palmer Sikelianos to May Suydam Palmer dated 17-30 September, no year, with a return address given as Upper Agorieni Parnassos, Eva Sikelianou Papers, Benaki Museum Historical Archives 189/26. The letter is filed among

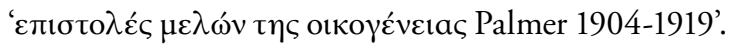

14. Eva signed her letter of 4 July 1924 to Natalie Clifford Barney, written on the way home to Sykia, 'I liked seeing you again. Love from Eva' (Papadaki 1995, 293). As above (see n. 10) the original text was in English, and mine is an approximation of that English translated from the Greek.

15. Naoroji's 'drain theory' is discussed in Ganguli 1965 and Chandra 1966. Seth 1999, 104 summarizes Naoroji's contribution thus: 'The economic complaints of the nationalist elite - over excessive taxation, wasteful government expenditures, military adventures paid for by India - were knitted together by Dadabhai Naoroji into a more comprehensive and damning claim, namely that England was enriching itself at the expense of India, via a "drain of wealth".

16. http://www.vohuman.org/Article/Dr.\%20Dadabhai\%2 0Naoroji.htm

17. Masani 1968, 10.

18. Palmer Sikalianos 1993, 97.

19. Palmer Sikelianos 1993, 51.

20. Eva Palmer Sikelianos letter to Natalie Clifford Barney written on the way to Sykia dated 4 July 1924. Papadaki 1995, letter 153.

21. Palmer Sikelianos 1993, 97.

22. Palmer Sikelianos 1993, 96.

23. Palmer Sikelianos 1993, 98.

24. Palmer Sikelianos 1993, 47. 
25. Palmer Sikelianos 1993, 48.

26. Palmer Sikelianos 1993, 49.

27. Palmer Sikelianos 1993, 48-49, quoting a letter written to her by Joan Vanderpool.

28. Palmer Sikelianos 1993, 78, 80.

29. Sikelianou 2005 is Eva's address to the Greek Archaeological Society, delivered on 16 May 1919, in which she argues on the basis of human creativity, health, freedom, and economic reasons that Greek women should exchange their Western dress for handwoven tunics.

30. Palmer Sikelianos 1993, 103.

31. Palmer Sikelianos 1993, 98.

32. Letter from Nurgis D. Captain to Eva dated 8 August 1924. Eva Sikelianou papers 189/27.

33. Palmer Sikelianos 1993, 99.

34. Palmer Sikelianos 1993, 99.

35. Undated letter from Khorshed Naoroji to Eva, Eva Sikelianou Papers 189/27 a-21.

36. Letter from Khorshed Naoroji to Eva dated 2 January 1925, Eva Sikelianou Papers 189/27 a-9.

37. Undated letter from Khorshed Naoroji to Eva, Eva Sikelianou Papers 189/27 a-13.

38. Letter from Khorshed Naoroji to Eva dated 20 December 1924, Eva Sikelianou Papers 189/27 a-7.

39. Letter from Khorshed Naoroji to Eva dated 20 December 1924, Eva Sikelianou Papers 189/27 a-7.

40. Letter from Khorshed Naoroji to Eva dated 3 February 1925, Eva Sikelianou Papers 189/27 a-10.

41. Undated letter from Khorshed Naoroji to Eva, Eva Sikelianou Papers 189/27 a-21.

42. Letter from Khorshed Naoroji to Eva dated 20 December 1924, Eva Sikelianou Papers 189/27 a-7.

43. Letter from Khorshed Naoroji to Eva dated 20 December 1924, Eva Sikelianou Papers 189/27 a-7.

44. Letter from Khorshed Naoroji to Eva dated 2 January 1925, Eva Sikelianou Papers 189/27 a-9.

45. Letter from Khorshed Naoroji to Eva dated 2 January 1925, Eva Sikelianou Papers 189/27 a-9.
46. Freud 1964, 248.

47. Letter from Khorshed Naoroji to Eva dated 2 January 1925, Eva Sikelianou Papers 189/27 a-9.

48. Letter from Khorshed Naoroji to Eva dated 3 September 1925, Eva Sikelianou Papers 189/27 a-14.

49. Letter from Khorshed Naoroji to Eva dated 3 September 1925, Eva Sikelianou Papers 189/27 a-14.

50. Letter from Khorshed Naoroji to Eva dated 16 September 1925, Eva Sikelianou Papers 189/27 a-15.

51. I am grateful to Dinyar Patel for sharing with me this information from his research on Gandhi and the Parsis. According to sources he has studied, Gandhi was supportive of Khorshed's musical endeavours and encouraged her to become accomplished in Indian music, something he recognized as very difficult.

52. 'Letter to C.F. Andrews' dated 15 June 1933; letter 211, Vol. 61, 163: http://www.gandhiserv.org/cwmg/cxmg.html.

53. 'Tit Willow', Time, Monday 25 September 1944, http: //www.time.com/time/magazine/article/0,9171,791650,00. html.

54. Letter from Khorshed Naoroji to Eva dated 18 May 1927, Eva Sikelianou Papers 189/28 a-16.

55. Letter from Eva Palmer Sikelianos to May Suydam Palmer dated 17-30 September, no year, with a return address given as Upper Agorieni Parnassos, Eva Sikelianou Papers 189/26.

56. Letter from Gandhi to Angelos Sikelianos dated 6 January 1927 and letter from Tagore to Angelos Sikelianos, Eva Sikelianou Papers 189/28. The letters from Gandhi and Tagore are among the unexplored treasures of the Eva Sikelianou Papers at the Benaki Museum Historical Archives. Addressing Angelos Sikelianos simply as 'Dear Poet', Tagore expressed his regrets that he would be unable 'to attend your festival and spend some time in your beautiful country'. He then promised, in the event that money and time allowed him to return to Europe, to 'utilize the opportunity in meeting you and,' Tagore added, 'arranging for writing down my songs in Greek notation'. That last phrase can only be explained in the light of Eva's collaboration with Khorshed Naoroji and her intention to export Byzantine notation to India.

57. Letter from Khorshed Naoroji to Eva dated 24 January 1936, Eva Sikelianou Papers 189/32, E2-1. 


\section{REFERENCES}

Chandra B. 1966: The Rise and Growth of Economic Nationalism in India (New Delhi).

Eva Sikelianou Papers (1860-1967): Benaki Museum Historical Archives (Athens, Greece).

Freud S. 1964: A Disturbance of Memory on the Acropolis. An Open Letter to Romain Roland on the Occasion of His Seventieth Birthday [1936], in: The Standard Edition of the Complete Psychological Works of Sigmund Freud Vol. 22 (1932-1936) (ed. and transl. by James Strachey; London) 239-48.

Gandhi M. K. 1955: Khadi: Why and How (ed. by Bharatan Kumarappa; Ahmedaban).

Ganguli Birendranath N. 1965: Dadabhai Naoroji and the Drain Theory (Bombay).

Goldhill S. 2002: Who Needs Greek? Contests in the Cultural History of Hellenism (Cambridge).

Masani, Rustom P. 1968: Dadabhai Naoroji: The Grand
Old Man of India (Mysore).

Palmer Sikelianos E. 1993: Upward Panic (ed. by John P. Anton; Philadelphia).

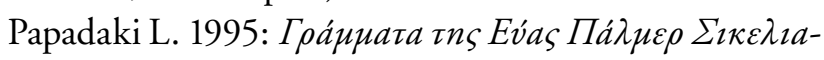
vov́ otn Natalie Clifford Barney (Athens).

Parel A. 1969: Symbolism in Gandhian Politics, Canadian Journal of Political Science / Revue canadienne de science politique 2, 513-27.

Roessel D. 2002: In Byron's Shadow: Modern Greece in the English and American Imagination (Oxford).

Seth S. 1999: Rewriting Histories of Nationalism: The Politics of Moderate Nationalism in India, 1870-1905, The American Historical Review 104, 95-116.

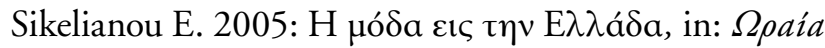

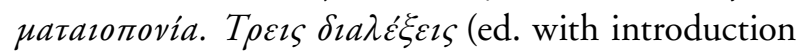
and notes by R. Frangou-Kikilia; Athens) 31-47. 
